\title{
POPULATION DYNAMICS OF REBA CARP CIRRHINUS REBA FROM INDUS RIVER, SUKKUR, SINDH, PAKISTAN
}

\author{
Khadim Hussain Memon*, Rashida Bhanbhro, Qun Liu ${ }^{1}$, Tahira Jabeen Ursani ${ }^{2}$, \\ Abdul Manan Shaikh and Sapna Waheed Memon \\ Department of Zoology, Shah Abdul Latif University Khairpur, Sindh, Pakistan
}

\begin{abstract}
Present work was done from Indus River, Sukkur, Sindh, Pakistan to evaluate the present stock of Cirrhinus reba Suhni (Reba carp) for first time. Since the assessment of stocks deliver the important knowledge of stocks of commercially important fish species to the fisheries managers to make better strategic plans for sustainable exploitation. Data based on length-frequency was obtained from October 2015 to March 2016, a total of 463 pairs of length-weight were measured. Minimum length was measured to $13 \mathrm{~cm}$, maximum length was $29 \mathrm{~cm}$ and the average length of $17 \mathrm{~cm}$ was measured with minimum weight of $15 \mathrm{~g}$, maximum weight of $224 \mathrm{~g}$ and $67 \mathrm{~g}$ was the average weight. Obtained results of length-weight relationship were $R^{2}=0.817, \mathrm{a}=0.037$ and $\mathrm{b}=2.557$. Growth parameters were computed as $L_{\infty}=29.40 \mathrm{cmand} k=0.240$ year $^{-1}$ using ELEFAN method in FISAT computer package. Growth performance index $\left(\emptyset^{\prime}\right)$ was calculated as $\emptyset^{\prime}=2.317$ year $^{-1}$. Total mortality $Z$, natural mortality $M$ and fishing mortality $F$ was estimated as $Z=0.630$ year $^{-1}, \quad M=0.617$ year $^{-1}$ and $F=0.012$ year $^{-1}$ respectively. Using $(E=F / Z)$ the exploitation ratio was obtained as $E=0.019$ year $^{-1}$. Current fishing mortality rate of 0.012 was smaller than the target biological reference points $\left(F_{\mathrm{opt}}\right)$ of $M(0.617)$. While MSY was recorded as; 8.144 tonsyear-1 $^{-1}$ which showed the higher results than 0.031 tons year ${ }^{-1}$ ofcurrent catch. This study concluded that the C. reba confronting poor health though the stocks found not to be overexploited in the region.
\end{abstract}

Key-words: Stock Assessment, Crirrhinus reba, Growth, Biological Reference Points, Length-Weight Relationship, Mortality

\section{INTRODUCTION}

Pakistan freshwaters are home of About 186 inland fish species (Khan et al.,2008). Amongst them Palla (Taenualosa ilisha), Rohu (Labeo rohita), Dahi (Labeo calbasu), Common carp (Cyprinus carpio), Morakhi (Cirrhinus cirrhosus), Thaila (Gibelion catla), Mahseer (Tor putitora) Mundha/Shakur (Amiacalva), Silver carp (Hypophthhalmichthys molitrix), Grass carp (Ctenopharyngodon idella), Khagga (Rita rita), Seengara (Sperata sarwari), tilapia (Oreochromis mossambicus), Reba carp (Cirrhinus reba) have most significant commercial values (Khan et al., 2008). In comparison of mutton, beef and chicken fish meat is considered as safe, healthy diet and one of the main sources of protein, swifter fat, vitamins and minerals (Astawan 2004). Many of the fishermen families rely economically on fisheries (MFD 2012), about 180000 people depends for their livelihood on fisheries sector (Fourth National Report 2009).

*Author for Corresponding: <khadim.memon@salu.edu.pk>, ${ }^{1}$ College of Fisheries, Ocean University of China; Qingdao 266003, P.R China, ${ }^{2}$ Department of Zoology, University of Sindh, Jamshoro, Pakistan

(C2020 Zoological Society of Bangladesh DOI: https://doi.org/10.3329/bjz.v48i1.47878 
The products of this sector are not only sent to the country side markets but they are also sent to the international markets for earnings but since last few decades in Pakistan the fisheries resources not only marine but freshwater as well are going to decline (Akhtar 2010). The reason may be the fisheries resources of Pakistan utilized improperly. No stock assessment surveys were conducted as well as they were exploited extraordinarily. It is necessary to improve this situation and proper stock assessment surveys may be conducted, otherwise it is a prediction that the stocks will be collapse up to 2048 (Worm et al., 2006). Since assessment of stocks predicts the best available information for managers of fisheries sector, through which they can make better planning for the sustainable utilization of the fisheries resources of the region (Ecoutin et al., 2005). This is because this study was conducted to know the stocks in Indus River Sukkur, Sindh, Pakistan of this commercially important fresh water fish species Cirrhinus reba (Hamilton 1822). The collection of age structured in tropical fisheries of developing countries is quite hard due to that the lengthweight was obtained, because these types of data are commonly applied in fisheries for stock assessment purposes (Sparre and Venema, 1998). For estimation of growth rates, mortality rates, biological reference points and growth performance index of the species, this technique is generally applied (Kohlers et al.,1995).

The freshwater fish species Reba Carp locally known as sunee or suhnee and scientific name is C. reba (Hamilton 1822) have a great economic value (Afroz and Begum 2014; Narejo 2006).The published maximum length ranges from 30 to $32.5 \mathrm{~cm}$ is an omnivorous bottom feeder species feeds on plankton, detritus, larvae of insects, mud, vegetables and crustacean fauna (Rahman 1989; Talwar and Jhingran 1991; Lashari et al.,2010). Ponds, swamped fields, canals, lakes, reservoirs, streams and rivers are home of this species (Menon 1999). In mountainous areas $C$. reba may tolerate in very low temperature of $8^{\circ} \mathrm{C}$. The breeding months of C.reba are May to October (Mathialagan and Sivakumar 2012; Lashari et al., 2007; Hossain 2001). The previously reported fecundity of this species is 22356-437,400 and 20722-211200 (Lashari et al., 2007).It is distributed throughout India, Nepal, Bangladesh and Pakistan (Mirza and Alam 2002). In literature some previously reported work is accessible on stock assessment of different species of marine waters from Pakistan such as: Memon et al., 2015 and 2016. While Narejo (2006) andMuhammad et al., (2016) reported length-weight relationship of $C$. reba from fresh waters of Manchar Lake Dadu, Sindh and Taunsa barrage at the Indus River, Punjab, Pakistan respectively, but no published work is yet reported from Indus River Sukkur, Sindh, Pakistan.

\section{MATERIAL AND METHODS}

Collection of Data: For the collection of data the fishermen were requested on charges to collect the samples from different sampling sites such as Alif Kacho, Bay Kachoand JeemKacho at Indus River bi-monthly from October 2015 to March 2016. Generally for fishing these sites are preferred by fishermen. The Bottom trawl (Ghaao) or (Rachh) net having a length of 300 feet with mesh size of 4" was used for collection of samples. The available literature, accounts and 
keys given by Talwar and Jhingran, (1991); Jayaram (1999) and Shrestha, (1981-1994) were used for identification of collected samples.

Data Analysis: The computer software package FiSAT II (FAO-ICLARM) was applied for computation of length frequency data (Gayanilo et al., 2003). The target parameters of selected fish species were growth rate, mortality rates and biological reference point and growth performance index.

Length-Weight Relationship: The Le Cren (1951) formula was applied to compute Length-weight relationship of C. reba.

$" W=a L^{b "}$

Where: $W=$ weight, $L=$ length, $a=$ constant condition factor and $b=$ allometric growth parameter (Le Cren1951).

Growth: The length with age of $C$. reba was estimated applying the von Bertalanffy Growth Function (VGBF).

$" L_{t}=L_{\infty}\left(1-\exp \left(-k\left(t-t_{0}\right)\right)\right) "$

Whereas $L_{t}=$ length at age $\mathrm{t}, L_{\infty}=$ asymptotic average maximum length, $K=$ growth coefficient and $t_{0}=$ theoretical age with length at zero (Haddon, 2011). It was calculated applying the equation of Pauly (1983):

$" \log _{10}\left(-t_{0}\right)=-0.3922-0.275 \log _{10} L_{\infty}-1.038 \log _{10} k "$

Mortality: The length-converted catch curve estimation technique was used for the computation of total mortality Z (Pauly 1983).

$" \operatorname{In}\left(N_{i} / \Delta t_{i}\right)=a+b \cdot t_{i} "$

Whereas: $N_{i}=$ the number of observed fish in length class i, $\Delta t_{i}=$ the time required for the fish to grow accordingly through length class $i, t_{i}=$ the age (or the relative age, computed with $t_{0}=0$ ) corresponding to the middle length of class $\mathrm{i}$, and $b$ with sign changed, is an estimate of $Z$.

Natural Mortality M was computed using the Pauly's formula:

$" \log _{10}(M)=0.006-0.279 \log _{10}\left(L_{\infty}\right)+0.654 \log _{10}(k)+0.6434 \log _{10}(T) "$

Where $L_{\infty}$ was in $\mathrm{cm}$ and $\mathrm{k}$ was in year ${ }^{-1}$. Taws the average water temperature.

The obtained natural mortality $M$ was subtracted from total mortality $Z$ to estimate the fishing mortality $(F)$, the $F / Z$ was applied to obtained the exploitation ratio $\mathrm{E}$.

Biological Reference Point: Gulland's formula was used for the estimation of biological reference point (Gulland, 1969). 
$" F_{o p t}=M "$

Growth performance index: It was estimated applying the formula of Pauly and Munro (1984).

$" \emptyset^{\prime}=\log _{10} k+2 \log _{10} L_{\infty} "$

Maximum sustainable yield: The formula of Gulland (1979) was used for the computation of Maximum sustainable yield.

"MSY $=Z \times 0.5 \times B "$

$Z=$ total mortality, $B=$ biomass. The $Y / F$ was used for estimation of biomass $(B)$, whereas $(Y)=$ the total observed yield in tons of the species of current studies and $(F)=$ the fishing mortality.

\section{RESULTS AND DISCUSSION}

\section{Length Frequency Distribution:}

Total 463 specimens were collectedwith a minimum length of $13 \mathrm{~cm}$ and maximum length of $29 \mathrm{~cm}$ (Fig.1), while the obtained average length was $17 \mathrm{~cm}$, meantime the computedminimum weight was $15 \mathrm{~g}$ and maximum was $224 \mathrm{~g}$, while the average observed weight was $67 \mathrm{~g}$, and total weight of all catches were 0.031 ton $(31.468 \mathrm{~kg})$.

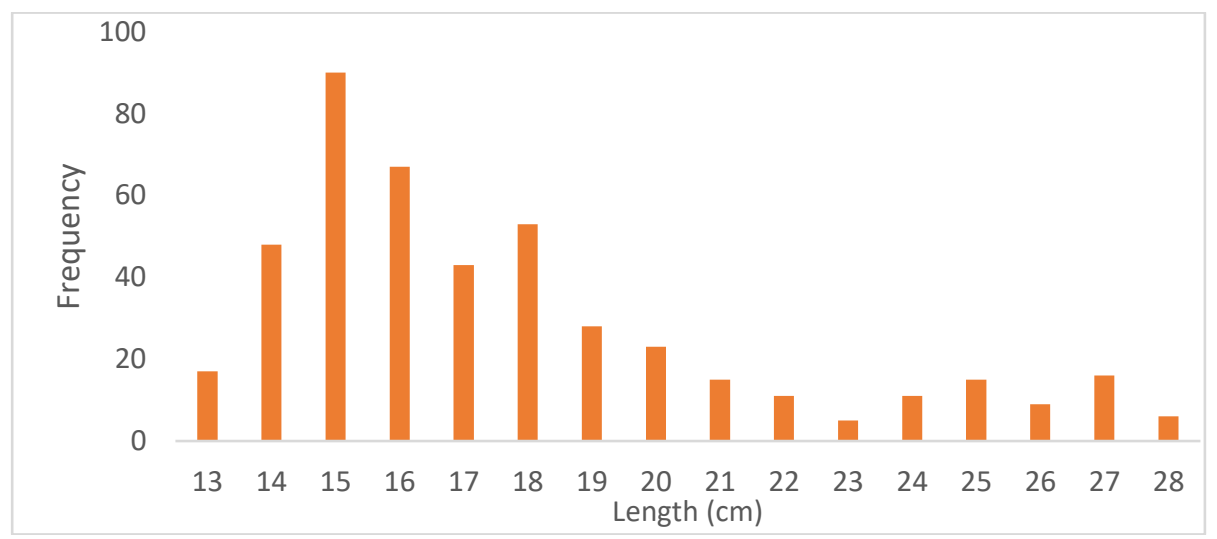

Fig.1: Shows the Length Frequency of Cirrhinus reba from Indus River Sukkur, Sindh, Pakistan

Length-Weight Relationships: Physical well-being of the fish species can be determined with the help of length-weight relationship. As per the given standard values for the well-being of fish species, i.e. obtained $b$ values of 3 indicate the isometric growth of the fish, b value less than 3 determine the negative allometric growth of the fish and $b$ values greater than 3 shows the 
positive allometric growth of the fish Gayanelo and Pauly (1997). Since the obtained values of length weight relationship in present study were $a=0.037$, $b=2.557$ and $R^{2}=0.817$ (Fig. 2). The $b$ values of 2.557 were less than 3 , which indicate the negative allometric growth of the fish at the study area.

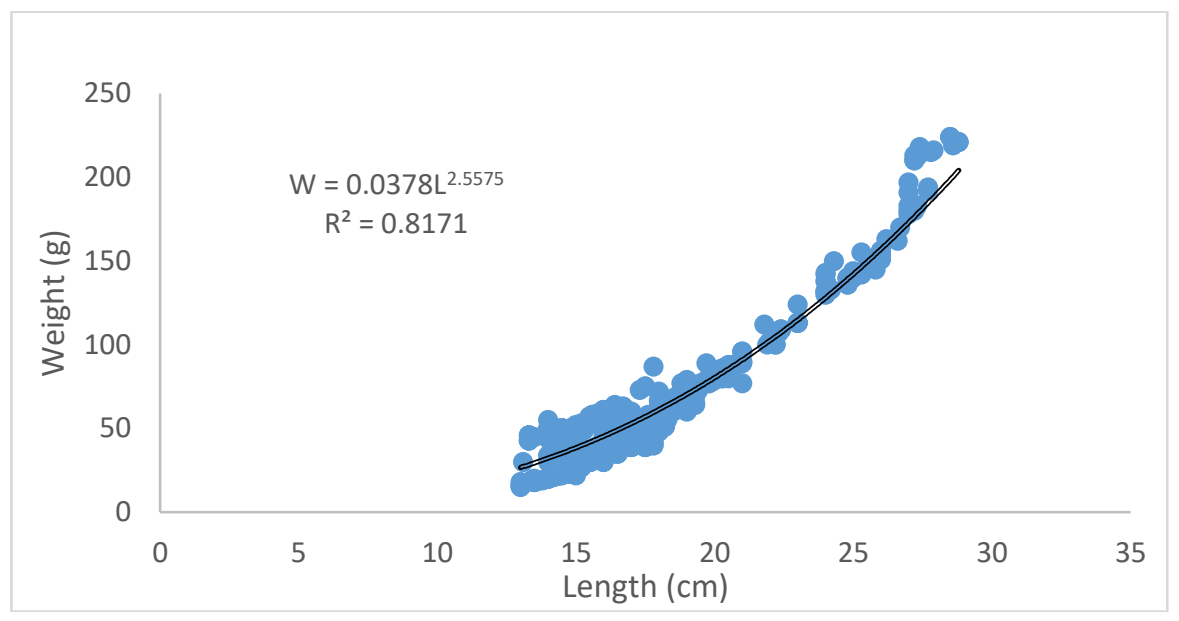

Fig.2: Shows the Length-Weight Relationship of Cirrhinus reba from Indus River Sukkur, Sindh, Pakistan

Growth Parameters: The growth parameters can be calculated using lengthfrequency data or they can be obtained using the absolute or relative age of the fish species. In present work the obtained results of growth parameters were $L_{\infty}=29.4 \mathrm{~cm}, \quad K=0.240$ year $^{-1}$ and theoretical age $t_{0}=-0.703$ year ${ }^{-1}$ as (Fig.3). Obtained results of $K=0.240$ year-1determined the low growth rate of fish species. There is a high relation between $K$ and $L_{\infty}$. Natural mortality $(M)$ demonstrated direct relation to the $(K)$ growth coefficient and indirectly related to the $\left(L_{\infty}\right)$ asymptotic length and the lifecycle (Beverton and Holt, 1956). Simply the fishes having higher growth coefficient have smaller lifespan and greater natural mortality. In this study the smaller $L_{\infty}$ and lower growth coefficient $(K)$ indicates longer life span and lower natural mortality.

Mortality: In present study the obtained results of total mortality, natural mortality and fishing mortality for C. Reba were $Z=0.63 y e a r^{-1}$ (Fig. 4), $M=$ 0.617 year $^{-1}$ and $F=0.012$ year $^{-1}$ respectively. The obtained exploitation ratio was $E=0.02$ year $^{-1}$ that isless than the optimum exploitation ratio $(E)$ of 0.5 (Gulland 1971) which indicates that the stocks of C. reba were not over exploited in the region. 


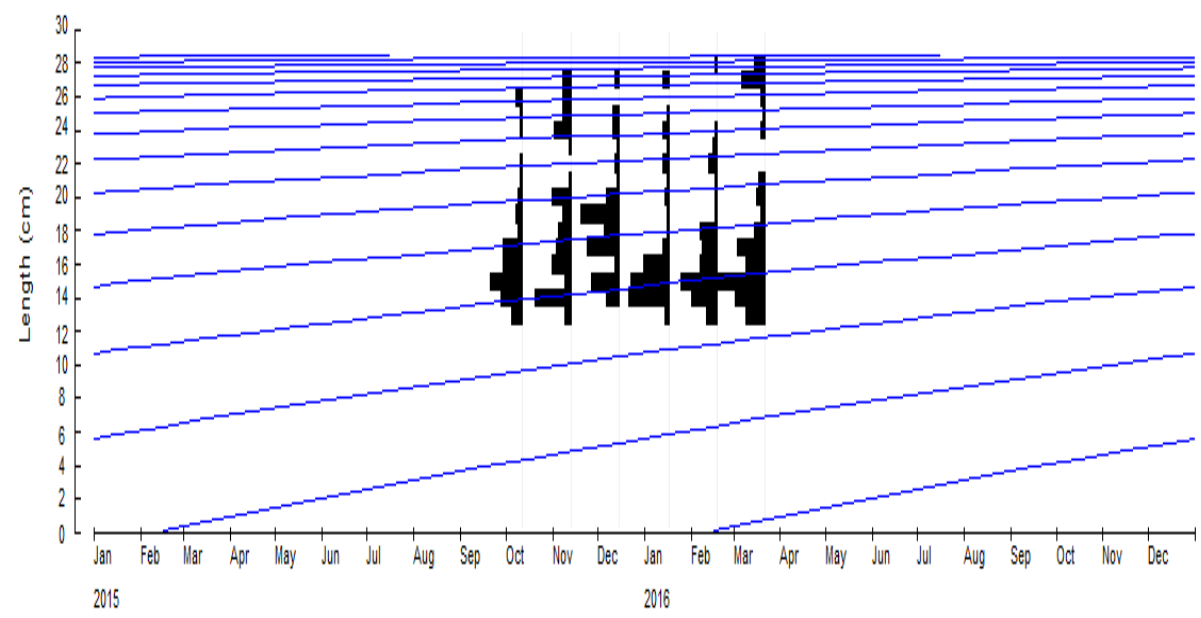

Fig.3:Shows the Length frequency distribution data and growth curve estimated using ELEFAN method of C. reba from Indus River Sukkur, Sindh, Pakistan

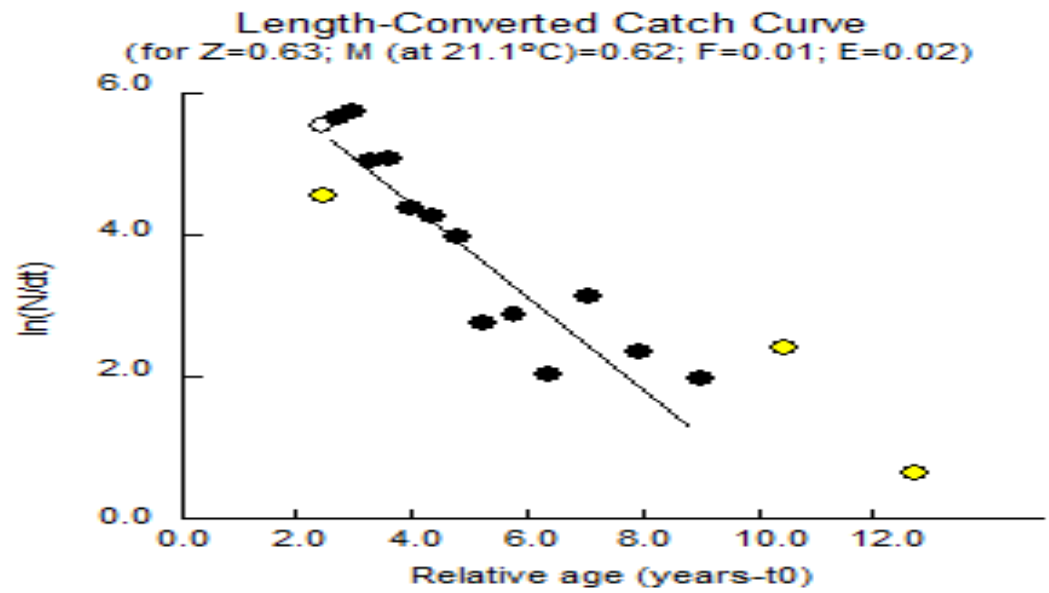

Fig.4: Shows the Length converted catch curve analysis of C. reba from Indus River, Sukkur, Sindh, Pakistan

Biological Reference Points: The calculated values of 0.617 for biological reference points were higher than the fishing mortality rate of 0.012 year $^{1}$.

Growth Performance Index: Obtained values of growth performance index for $C$. reba were $\emptyset^{\prime}=2.317$ year $^{-1}$.

Maximum Sustainable Yield: The obtained values of MSY of 8.144 tons year ${ }^{-1}$ were higher than recent catch of 0.0314 tons year ${ }^{-1}(31.468 \mathrm{~kg})$. Length-Weight Relationship: Information about the seasonal changes, about 
definite location about the well-being of fish species can be obtained using the data of length-weight relationship. Beside this it is also describes the allometric or isometric growth of fish which is said to be the significant characteristic for fish population dynamics. Obtained results of length-weight relationship of current work were matched with the previously published values of lengthweight relationship (Table 1). The acquired results of Narejo (2006) for lengthweight relationship were $b=3.32$ and $R^{2}=0.99$, which were higher than the results of present study and determined the positive allometric while the obtained values of length-weight relationship of Mathialagan et al.,(2014) for C. reba from India were $b=2.385$ and $R^{2}=0.871$, which near to similar of our results of $b=$ 2.557 and $R^{2}=0.817$ and described the negative allometric growth(Allen 1938). The results of different authors were shown in (Table 1) which indicated that some individuals of fish species do not fit in the cube law because these fishes may have changed their form with growth (Javaid and Akram 1972; Sinha 1975). This may be due to several reasons such as presence of food, spawning and maturity conditions and due to sex differences (Le Cren 1951; Naeem et al., 1992; Salam et al., 1994; Ali et al., 2000).

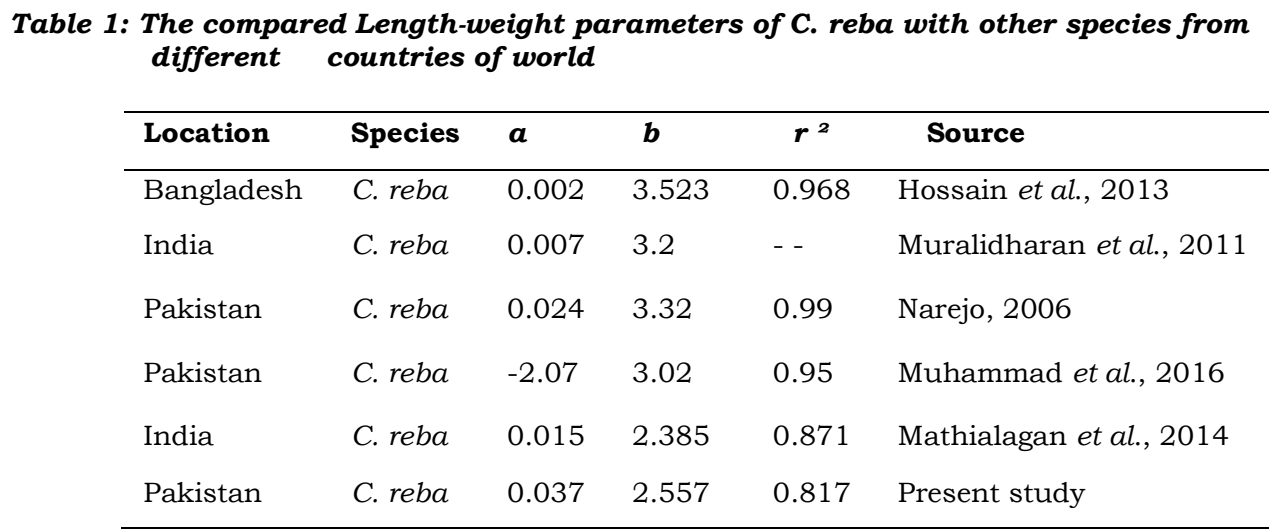

Growth Parameters: To calculate the growth parameters of fish species VBGF is generally applied which is formulated to study the anabolic and catabolic process in species and the growth as equilibrium (Pauly 1980). Computed values of growth parameters $L_{\infty}=29.40 \mathrm{~cm}$ and $K=0.240$ year $^{-1}$ were shown in (Table 2).The obtained results of the study of Gheorghe et al., (2012) for Carassius gibelio were $L_{\infty}=39.38$ and $K=0.63$,from Romania, which were higher than computed values of $C$. reba in present study. The low growth rate of the species was determined from present study with $K\left(0.240\right.$ year $\left.^{-1}\right)$. The $t_{0}$ with negative results describes that juveniles grew faster than the predicted growth curve for adults and the juvenile fish species grow slowly if the $t_{0}$ results found to be positive (King, 1995). In this work estimated values of $t_{0}$ were $_{0}=-0.70$ year $^{-1}$. 
Mortality: Previously published values of mortality of different authors were compared with the obtained results in present study (Table 3). The obtained results of Carassius gibelio of Gheorghe et al., 2012 for total mortality, natural

Table 2: The compared Growth parameters of C. reba with different species of the world

\begin{tabular}{lllll}
\hline \multicolumn{1}{c}{ Location } & \multicolumn{1}{c}{ Species } & L $\infty$ cm & k year-1 & \multicolumn{1}{c}{ Source } \\
\hline India & Tor khudree & 120.2 & 0.23 & Raghavan et al., 2011 \\
Bangaladesh & Cirrhinus cirrhosus & 85 & 0.43 & Ahmad et al., 2004 \\
Pakistan & Cyprinus carpio & 80.33 & 0.6 & Mirza, 2012 \\
Romania & Carassius gibelio & 39.38 & 0.63 & Gheorghe et al., 2012 \\
Pakistan & Cirrhinus reba & 29.4 & 0.24 & Present work \\
\hline
\end{tabular}

mortality and fishing mortality were 2.29 year $^{-1}, 1.46$ year $^{-1}, 0.826$ year $^{-1}$ and exploitation ratio was 0.63 year $^{-1}$, the results of Mirza 2012 for Cyprinus carpio from Pakistan were $Z=1.22$ year $^{-1}, M=0.890$ year $^{-1}, F=0.330$ year $^{-1}$ and $E=$ 0.690 year $^{-1}$. The obtained results from different countries were higher than the obtained results of present study. Meantime the obtained exploitation rate of 0.02 year $^{-1}$ was smaller than that of the standard exploitation rate of 0.5 year $^{-1}$ (Gulland 1971).

Table 3: The compared Mortality rates of C. reba with different species of world

\begin{tabular}{lllllll}
\hline Location & \multicolumn{1}{c}{ Species } & Zyearl $^{-1}$ & Myearl & Fyear'l & Eyear'l & \multicolumn{1}{c}{ Source } \\
\hline Romania & Carassius gibelio & 2.29 & 1.46 & 0.826 & 0.63 & Gheorghe et al., 2012 \\
Pakistan & Cyprinus carpio & 1.22 & 0.890 & 0.330 & 0.690 & Mirza, 2012 \\
India & Torkhudree & 0.350 & 0.220 & 0.130 & 0.340 & Raghavan, 2011 \\
Pakistan & Cirrhinus reba & 0.630 & 0.617 & 0.012 & 0.019 & Present study \\
\hline
\end{tabular}

Biological Reference Points: In present study the computed values of biological reference pointsfor C. reba were 0.618 year $^{-1}$ and the obtained results of fishing mortality were 0.012 year $^{-1}$ which indicates that the studied fish species were at a sustainable level.

Growth Performance Index: The results of growth performance index $\left(\emptyset^{\prime}\right)$ provides the diverse biological information about thestatus of various stocks or population (Baijot and Moreau, 1997). In present study the obtained values for growth performance index were $\emptyset^{\prime}=2.317 y^{2} a^{-1}$. Since, in current work the data is not enough so that it cannot be compared to the parameters of lifespan of other studies. This may raise some concerns for the fishery managers.

Maximum Sustainable Yield: Computed results of MSY in present work were 8.144 tons year $^{-1}$. The obtained values were greater than the present catches of 0.031 tons year $^{-1}(31.468 \mathrm{~kg})$, which indicates that the stocks of this species may be at a sustainable level in the region. 


\section{CONCLUSION}

Estimated values of fishing mortality $(F)$ and maximum sustainable yield (MSY) indicated that the studied fish species of C. reba were at sustainable level in Indus River Sukkur, Sindh, Pakistan.

Acknowledgements: Higher education of Pakistan (HEC) supported this work through (Project No. 597).

\section{LITERATURE CITED}

AFROZ H and BEGUM M 2014. Analysis of nutritional value and mineral contents of three different parts of body of Cirrhinus reba. International Journal of Science and Engineering Research, 5: 2301-2306.

AHMAD KKU, AMIN SMN, HALDAR GC and MAZID MA 2004.Population dynamics of Cirrhinus mrigala (Hamilton) in the Kaptai reservoir Bangladesh. Indian Journal of Fisheries, 51(3): 325-333.

AKHTAR N 2010. Enterprises Based Fisheries Sector Study and Strategic Plan for Interventions at Enterprise's Level to Enhance Quality production. United Nation Industrial Development Organization Trade Related Technical Assistance (TRTA II) Program.

ALI M, SALAM A and IQBAL F 2000. Weight-length and condition factor relationship of wild Channa punctata from Multan. Punjab University Journal of Zoology, 15: 183-189.

ALLEN KR 1938. Some observations on the biology of the Trout (Salmotrutta) in winderemere, Journal of Animal Ecology, 7: 333-349.

ASTAWAN M 2004. Ikan yang sedapdanbergizi. Solo: Tiga Sserangkai.

BAIJOT E AND MOREAU J 1997. Biology and demographic status of the main fish species in the reservoirs of Burkina Faso, E. Baijot, J. Moreau and S. Bouda eds. Hydrological Aspects of Fisheries in Small Reservoirs in the Sahel Region. Technical Centre for Agricultural and Rural Cooperation, Commission of the European Communities, Wageningen, Netherlands, pp. 79-109.

BERTALANffY L 1951. Theoretische Biologie. Zweiter Band: Stoffwechsel, Wachstum. A. Francke AG Verlag, Bern, pp. 418.

BEVERTON RJH and HOLT SJ 1956. A review of method for estimating mortality rates in exploited fish population, with special reference to source of bias in catch sampling. Rapports et Proces Verbaux des Reunions International Council for CIEM, 140: 67-83.

ECOUTIN JM, ALBARET JJ and TRAP S 2005. Length-weight relationships for fish populations of a relatively undisturbed tropical estuary: The Gambia. Fish Research, 72: 347-351.

FOURTH NATIONAL REPORT 2009.Government of Pakistan Ministry of Environment Islamabad Print.

GAYANILOFC, SPARRE P and PAULY D 2003. FAO ICLARM Stock Assessment Tool (FISAT-II), User's guide FAO Computerized Information Series (Fisheries). 8, Rome, FAO, pp: 266.

Gheorghe DC, Enache IB, Cristea V and Răzlog GP 2012. Characteristics of the population growth and mortality of carp in the Danube (Km 170 - Km 196). Lucrări Ştiințifice-SeriaZootehnie, 5: 164-169.

GULLAND JA 1969. Manual of Methods of Fish Stock Assessment Part I. Fish Population Analysis, Fishery Resources and Exploitation Division, FAO, Rome, pp: 154.

GULLAND JA 1971. The Fish Resources of the Oceans West By fleet, Surrey News (Books). Lts for FAO, 255.

HADDON, M 2011. Modeling and Quantitative Methods in Fisheries, Chapman \& Hall/ CRC Press London, pp: 449.

HOSSAIN QZ 2001. Induced breeding of the fish Cirrhinus reba by pituitary gland extract and survival of spawn in nursery ponds. Journal Asiatic Society of Bangladesh. Vol. 27: pp. 205213. 
HOSSAIN Y, KHATUN M, JASMINE S, RAHMAN M, JAHAN S, JEWEL A S and OHTOMI J 2013. Lifehistory Traits of the Threatened Freshwater Fish Cirrhinus reba (Hamilton 1822) (Cypriniformes: Cyprinidae) in the Ganges River, Northwestern Bangladesh. Sains Malaysiana 42(9): 1219-1229.

JAVAID M Y and AKRAM M 1972. The length-weight relationship and condition factor of seven fresh water fishes of Pakistan. Bull. Dept. Zool. Punjab Univ. Lahore., 6: 1-27.

JAYARAM KC 1999. The freshwater fishes of the Indian region. Narendra Publishing House, Delhi, India, pp: 551.

JHINGRAN VG 1968. General length- weight relationship of three major carps of India.Proceedings of the National Institute of Sciences of India,18: 449-460.

KHAN AM, SHAKIR HA, KHAN MN, ABID MAND MIRZA MR 2008. Ichthyofaunal Survey of Some Fresh Water Reservoirs In Punjab. Journal of Animal Plant Science, 18(4): 151-154.

KING M (1995).Fisheries Biology, Assessment and Management. Fishing News Books.

LASHARI PK, NAREJO NT, LAGHARI MY and MASTOI AM 2007. Studies on the Gonado Somatic Index and fecundity of a carp Cirrhinus reba (Hamilton) from fish ponds of district Jacobabad, Sindh, Pakistan. Pakistan Journal of Zoology, 39: 95-98.

LE-CREN ED 1951.The length - weight relationship and seasonal cycle in gonad weight and condition in the perch (Percafluviatilis). Journal of Animal Ecology, 20: 201-219.

MATHIALAGAN Rand SIVAKUMAR R 2012. Gonado-somatic index of reba carp Cirrhinus reba (Hamilton) from Vadavar river, Lower Anicut, Tamil Nadu. Environmental Ecology, 30: 624626.

MATHIALAGAN R, SIVAKUMAR R, RAJASEKARAN N and CHANDRASEKAR S 2014. Length frequency distribution and length-weight relationship of reba carp Cirrhinus reba (Hamilton, 1822 Cypriniformes: Cyprinidae) from Lower Anicut, Tamil Nadu, 2(2):

MEMON KH, LIU Q, KALHORO MA, CHANG MS, BAOCHAO L, MEMON AM, HYDER S and TABASSUM S 2016. Growth and Mortality Parameters of Hairtail Lepturacanthus savala from Pakistan Waters. Pakistan Journal of Zoology. 48 (3): 829-837.

MEMON KH, LIU Q, KALHORO MA, NABI A and KUI Z 2015. Maximum sustainable yield estimates of Barramundi Latescal carifer fishery from Pakistani waters. Indian Journal of Geo-Marine Science.44(6):825-832.

MENON AGK 1999. Check list-fresh water fishes of India. Records of the Zoological Survey of India, Miscellaneous Publication, pp. 175.

MFD 2012. Hand book of fisheries statistics of Pakistan. A publication of Marine Fisheries Department, Government of Pakistan. Ministry of Food, Agriculture and Cooperatives (Livestock Division), 20: 215.

MIRZA MR and ALAM MK. 2002. A checklist of the fishes of the Punjab, Pakistan. Records of the Zoological Survey of Pakistan, 14: 31-35.

MIRZA ZS, NADEEM MS, BEG MA and QAYYUM M 2012. Population status and biological characteristics of common carp, Cyprinus carpio, In Mangla Reservoir (Pakistan).Journal of Animal and Plant Science, 22(4): 933-938.

MUHAMMAD H, IQBAL $Z$ and AKHLAQ T 2016. Length-weight, length-length relationships and condition factor of fishes of family Cyprindae from the Indus River, Pakistan. Punjab University Journal of Zoology, 31(2): 143147.

MURALIDHARAN M, ARUNACHALAM M and RAJA M 2011. Length-weight relationships for fish species from Cauvery River at Hogenakal in South India. Journal of Applied Ichthyology, 27: 968-969.

NAEEM M, SALAM A and KHAN MN 1992. Morphometric studies of an exotic fish, Oreochromisniloticus in relatin to bdy size. Proc. Pakistan Congress of Zoology, 12: 599-605.

NAREJO NT (2006). Length-Weight Relationship and Relative Condition Factor of a Carp, Cirrhinus reba (Hamilton) from Manchar Lake, Distt. Dadu, Sindh, Pakistan. Pakistan Journal of Zoology, 38(1): 11-14.

PAULY D 1983. Some simple methods for assessment of tropical fish stocks: FAO Fisheries Technical, 234, 52.

PAULY D and GAYANILO FC 1996. Estimating the parameter of length-weight relationships from length frequency samples and bulk weight. p. 136.in D. Pauly and P. Martosubroto (eds.) Baseline studies of biodiversity: the fish resources of western.

PAULY D and MUNRO JI (984. Once more on the comparison of Growth in fish and Invertebrates, Fish Byte, 2: 21-23. 
RAGHAVAN R, ALI A, DAHANUKAR N and ROSSER A 2011. Is the Deccan Mahseer, Tor khudree (Sykes, 1839) (Pisces: Cyprinidae) fishery in the Western Ghats Hotspot sustainable? A participatory approach to stock assessment. Fisheries Research, 110: 29-38.

RAHMAN AKA (989. Freshwater Fishes of Bangladesh. Zoological Society of Bangladesh. Department of Zoology, University of Dhaka, Dhaka 1000, pp: 364.

SALAM A, CHATTA AM, ZAMAN QU, AKHTAR QA and KHAN S 1994. Weight- length and condition factor relationship of a fresh water hatchery reared rainbow trout, Oncorhynchus mykiss from swat, Pakistan. Acta Science, 4: 67-72

SHRESTHA J 1981. Fishes of Nepal Curriculum Development Centre, Tribhuvan University, Kathmandu, Nepal, pp: 318. Print.

SHRESTHA J (1994).Fishes, fishing implements and method of Nepal. Published by Smt. M.D.

SINHA AL 1975. Length - weight relationship of a fresh water cat fish, Clarias batrachus (Dinn). Indian Journal of Zoolology, 14: 97-102.

SPARRE P and VENEMA SC 1998. Introduction to tropical fish stock assessment, Part 1: Manual, FAO Technical Paper, pp: 306.

TALWAR PK and JHINGRAN AG. 1991.Inland Fishes of India and Adjacent Countries. Oxford-IBH Publishing Co. Pvt. Ltd., New Delhi 1, 541

(Manuscript received on 11 September 2019; revised on 20 June, 2020) 